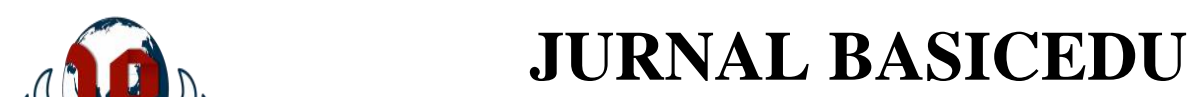

Volume 5 Nomor 2 Tahun 2021 Halaman 920-929

Research \& Learning in Elementary Education https://jbasic.org/index.php/basicedu

PAHLAWAN

\title{
Pengembangan LKPD Matematika Berbasis Problem Based Learning di Sekolah Dasar
}

\author{
Refki Effendi $^{1 凶}$,Herpratiwi $^{2}$, Sugeng Sutiarso ${ }^{3}$ \\ Program Studi Magister Teknologi Pendidikan, Pasca Sarjana Universitas Lampung ${ }^{1,2}$ \\ Program Studi Magister Pendidikan Matematika, Pasca Sarjana Universitas Lampung ${ }^{3}$ \\ Email : refkieffendi@gmail.com ${ }^{1}$, herpratiwi64@yahoo.com ${ }^{2}$, $\underline{\text { sugengsutiarso7@gmail.com }}^{3}$
}

\begin{abstract}
Abstrak
Tujuan penelitian untuk mengembangkan LKPD Matematika berbasis Problem Based Learning Materi FPB dan KPK kelas V Sekolah Dasar. Pengembangan LKPD Matematika dilator belakangi oleh kebutuhan pembelajaran yang dapat meningkatkan kemampuan peserta didik dalam pemecahan masalah, kemampuan dalam berfikir kritis serta menumbuhkan rasa ingin tahu. Jenis penelitian ini adalah penelitian pengembangan (research and development/R\&D). Tahapan utama dalam penelitian dan pengembangan ini adalah (1) pengumpulan informasi dan penelitian pendahuluan; (2) perencanaan; (3) pengembangan produk; (4) pengujian terbatas, dan (5) revisi produk akhir. Populasi dalam penelitian ini adalah pendidik kelas V SD Negeri kecamatan Tegineneng. Teknik pengambilan sampel yang digunakan adalah teknik purposive sampling. Sampel penelitian adalah 3 (tiga) guru kelas V SDN 28 Tegineneng, SDN 20 Tegineneng, dan SDN 1 Tegineneng. Teknik pengumpulan data menggunakan observasi dan angket. Teknik analisis data dalam penelitian ini menggunakan teknik analisis deskriptif kualitatif. Berdasarkan hasil penelitian dan pembahasan dapat disimpulkan bahwa pengembangan materi LKPD berbasis PBL di Sekolah Dasar sangat layak untuk digunakan dalam pembelajaran. Hal tersebut berdasarkan hasil validasi ahli materi sebesar $92,17 \%$, hasil validasi ahli desain sebesar $86,67 \%$, hasil validasi ahli media sebesar 89,56\% dan hasil tes kepada guru sebesar 92,13\%.
\end{abstract}

Kata Kunci : LKPD, Matematika, Problem Based Learning.

\begin{abstract}
The objective of this research is to develop students' worksheet using problem based learning on FPB and KPK materials in fifth grade of elementary schools. The development of Mathematics worksheet is based on the need for learning that can improve students' problem solving skills, critical thinking skills, and foster curiosity. This is type of research and development/R\&D which main stages are (1) collecting information and preliminary research; (2) planning; (3) product development; (4) limited examiners, and (5) final product revisions. The population in this research were teachers of class $V$ in SD Negeri Tegineneng Distric. The sampling technique used was purposive sampling technique. The research sample was 3 (three) grade V teachers of SDN 28 Tegineneng, SDN 20 Tegineneng, and SDN 1 Tegineneng. Technique of data collection used observation and questionnaires. The data analysis technique used in this study was a descriptive qualitative analysis technique. Based on the results of research and discussion, it can be concluded that the development of PBL based LKPD materials in elementary schools is very suitable to use in learning. This is based on the results of the validation of the material experts of $92.17 \%$, the results of the validation of the design experts of $86.67 \%$, the results of the validation of the media experts by $89.56 \%$ and the results of the test to the teacher of $92.13 \%$.
\end{abstract}

Keywords: students' worksheet, Mathematics, Problem Based Learning.

Copyright (c) 2021 Refki Effendi, Herpratiwi, Sugeng Sutiarso

Corresponding author:

Email: refkieffendi@gmail.com

DOI $\quad$ : https://doi.org/10.31004/basicedu.v5i2.846

ISSN 2580-3735 (Media Cetak)

ISSN 2580-1147 (Media Online)

Jurnal Basicedu Vol 5 No 2 Tahun 2021

p-ISSN 2580-3735 e-ISSN 2580-1147 


\section{PENDAHULUAN}

Pendidikan abad 21 mengharuskan peserta didik mengelola informasi yang mereka pelajari melalui kegiatan menganalisis, menilai, dan mengkreasi. Menurut (Bialik \& Fadel, 2015:5) kemampuan yang harus dimiliki peserta didik pada abad 21 ini adalah Creativity, Critical Thingking, Communication, and Collaboration. Peserta didik harus mampu menggunakan informasi yang diperoleh untuk menciptakan sesuatu yang baru, mampu membuat pendapat yang masuk akal, mengkomunikasikan pengetahuan yang diperoleh, dan bekerjasama dengan peserta didik lain untuk membangun kemampuan yang lebih optimal.

Kemampuan berpikir kritis merupakan satu diantara kemampuan yang harus dimiliki peserta didik untuk dapat memecahkan berbagai masalah. Menurut (Susanto, 2016) Kemampuan berpikir kritis adalah kemampuan untuk menganalisis sesuatu berdasarkan data atau informasi yang tersedia dan menemukan banyak kemungkinan jawaban terhadap satu masalah yang penekanannya pada kuantitas, ketepatgunaan, serta keragaman hasil jawaban. Berpikir kritis lebih kaya dari pada berpikir kreatif. Jika berpikir kreatif dapat menjawab persoalan atau kondisi yang dihadapinya, sedangkan berpikir kritis mampu memperkaya cara berpikir dengan alternatif yang beragam. Kemampuan berpikir kritis penting dimiliki peserta didik dalam memecahkan permasalahan. Hal ini karena pemikiran kritis adalah kemampuan dasar yang harus dikembangkan di sekolah.

Pengembangan kemampuan merupakan tujuan pendidikan nasional, salah satunya adalah kemampuan berpikir secara kritis. Tugas utama pendidikan adalah menciptakan manusia yang mampu melakukan sesuatu yang baru. Pentingnya kemampuan berpikir kritis merupakan salah satu kemampuan di dunia pendidikan. Dalam hal ini rendahnya kemampuan berpikir kritis dapat ditunjukkan dari hasil jawaban tentang kemampuan berpikir kritis yang peneliti lakukan saat pengambilan data awal. Dalam proses pembelajaran, guru jarang atau tidak pernah memunculkan kemampuan berfikir kritis. guru yang sebenarnya selama proses pembelajaran sudah baik, namun guru kurang memperhatikan kegiatan belajar siswa yang mengarah pada proses berpikir kritis. guru memegang peranan penting dalam keberhasilan siswa dalam pembelajaran, guru tidak hanya mentransfer ilmu, tetapi guru juga memfasilitasi kegiatan pembelajaran sehingga siswa dapat berpartisipasi aktif dalam kegiatan pembelajaran. Berfikir kritis merupakan salah satu budaya bangsa dan karakter. Pembelajaran kreatif juga penting dalam meningkatkan kualitas pembelajaran, demikian pula kreativitas kompetensi dalam hal proses dan hasil pembelajaran.

Matematika merupakan mata pelajaran yang mengandung berbagai kebutuhan hidup, salah satunya adalah sarana pendidikan. Matematika sebagai sarana pendidikan berperan dalam aktivitas manusia yang diperoleh dari proses berfikir, dan itu pun tidak diperoleh dari hasil percobaan (Damayanti \& Mawardi, 2018).

Matematika digunakan untuk melatih kemampuan berpikir dan bernalar sehingga dapat menyelesaikan masalah dalam kehidupan nyata. Menurut (Sriwongchai, 2015), mathematics is the science of thingking and important thing to enhance thingking potency in learning process. This because to learn concepts and solve the problem in mathematics well, critical and cretaive thinking skills is needed. Tujuan matematika bukan hanya membuat siswa mampu memanfaatkan matematika secara teoritis namun juga aplikatif, mempunyai kemampuan bernalar yang logis dan kritis dalam pemecahan masalah.

Hasil observasi menunjukkan bahwa pembelajaran lebih menerapkan teacher centered approaches yaitu pendidik menjadi pusat informasi bagi siswa, sehingga pembelajaran cenderung konvensional. Pola pembelajaran ini lebih kepada keaktifan pendidik dibandingkan dengan peserta didik. Selain itu, pendidik menganggap bahwa pembelajaran di kelas hanya untuk menuntaskan materi yang ada di buku saja. Peserta didik dipandang sebagai objek bukan sebagai subjek pembelajaran sehingga peserta didik kurang aktif dalam mengeksplorasi pengetahuan. 
Berdasarkan data hasil belajar dapat diketahui bahwa di SDN 28 Tegineneng dari 28 siswa, 13 siswa belum mencapai kriteria ketuntasan minimal (KKM) dengan persentase ketidaklengkapan 46,42\%. Di SDN 20 Tegineneng ada 17 siswa dari 30 siswa yang belum mencapai KKM dengan persentase ketidaklengkapan 56,67\%. di SDN 1 Tegineneng, dari 32 siswa terdapat 15 siswa yang belum mencapai KKM bersama persentase ketidaklengkapan sebesar 46,68\%. Jadi rata-rata siswa yang belum mencapai KKM matematika dari tiga sekolah dasar adalah 52,07\%. Berdasarkan (Depdiknas, 2006) Persentase ini Ketidaklengkapan relatif rendah karena idealnya pembelajaran dikatakan berhasil jika minimal $75 \%$ siswa mampu mencapai kriteria ketuntasan minimal.

LKPD diartikan sebagai bahan ajar cetak berupa lembaran kertas berisi bahan, ringkasan, dan petunjuk pelaksanaan tugas pembelajaran yang harus dilakukan oleh peserta yang mengacu pada Kompetensi Dasar (KD) yang harus dicapai (Prastowo, 2011).

Hal ini menurut definisi LKPD menurut (Trianto, 2010) adalah pedoman siswa yaitu digunakan untuk mengembangkan aspek kognitif sekaligus sebagai pedoman untuk mengembangkan semua aspek dalam bentuk pembelajaran pedoman untuk menyelidiki atau memecahkan masalah sesuai dengan indikator prestasi belajar yang harus dicapai. (Choo dkk., 2011) mengemukakan bahwa LKPD merupakan perangkat pembelajaran yang terdiri dari rangkaian pertanyaan dan informasi yang dirancang untuk memahami ide-ide kompleks, yang membimbing siswa untuk melaksanakannya kegiatan secara sistematis.

Menurut (Yasir, 2013) LKPD merupakan stimulus atau bimbingan guru dalam pembelajaran yang akan dilaksanakan disajikan secara tertulis sehingga dalam menulis perlu memperhatikan kriteria media grafis sebagai visual media untuk menarik perhatian siswa. Isi pesan LKPD harus memperhatikan elemen penulisan media grafis, hierarki materi dan pemilihan soal secara efisien dan efektif.

Berdasarkan hasil wawancara dengan guru SD kelas V di SDN Kecamatan tegineneng, diperoleh informasi bahwa penggunaan LKPD matematika belum mampu mengoptimalkan potensi dan kreativitas siswa dalam menguasai konsep matematika. Selain itu, kegiatan belajar dalam LKPD kurang variatif, lebih didominasi oleh kegiatan mengerjakan masalah yang berorientasi pada kecerdasan matematis logis. Padahal, pada hakikatnya setiap siswa memiliki kecerdasan yang berbeda-beda.

Dalam pendidikan dasar dan tinggi di banyak negara, termasuk Indonesia, apa yang menjadi bagian dari kurikulum konvensional pada matematika dan Sains sedangkan Teknologi dan Teknik hanya menempati porsi yang sangat kecil dalam kurikulum.

Keterlibatan peserta didik dalam kegiatan pembelajaran yang aktif lebih ditekankan dalam pembelajaran yang terarah sehingga diperoleh berbagai pengetahuan yang dipelajari secara holistik, bermakna, autentik dan aktif. Pembelajaran berbasis Problem Based Learning merupakan sebuah pembelajaran yang menyajikan masalah kontektual sehingga merangsang peserta didik untuk belajar. (Ronis, 2001: 33) menjelaskan bahwa "pembelajaran berbasis masalah sangat efektif dalam proses pembelajaran siswa karena memperkuat karakteristik pembelajaran. Melalui Problem Based Learning pembelajaran dikaitkan dengan masalah konstektual yang dekat dengan lingkungan sehari-hari sehingga peserta didik lebih mudah memahami isi pelajaran, mengakaitkan isi dengan lingkungan sekitar sehingga pembelajaran menjadi bermakna (meaningfull learning)".

Problem Based Learning juga merupakan sebuah model pembelajaran yang merubah paradigma belajar dari berpusat pada guru (teacher center) menjadi pembelajaran yang berpusat pada siswa (students center). Problem Based Learning dalam pembelajaran berawal dari masalah yang telah dipilih sehingga siswa tidak saja mempelajari konsep yang memiliki hubungan dengan masalah dan metode ilmiah yang digunakan dalam pemecahan masalah tetapi juga menjadi landasan dalam pembentukan karakter siswa, karena itulah 
Problem Based Learning merupakan salah satu model pembelajaran yang digunakan dalam kurikulum 2013. Dengan menggunakan model Problem Based Learning diharapkan pembelajaran akan lebih bermakna dan bermamfaat bagi siswa dalam kehidupan sehari-hari.

Pembelajaran model Problem Based Learning tidak hanya dilakukan dalam pelaksaan pembelajaran saja namun juga dalam bentuk LKPD sebagai panduan bagi guru dan sebagai bentuk kegiatan belajar pada siswa. LKPD berbasis model Problem Based Learning diharapkan mampu meningkatkan berfikir kritis siswa di sekolah dasar. Dalam observasi dan wawancara yang dilakukan dengan peserta didik dan guru di SDN Kecamatan Tegineneng Kabupaten Pesawaran diketahui LKPD yang digunakan siswa, belum menuntun siswa untuk dapat memecahkan masalah secara langsung karena LKPD yang digunakan adalah dari penerbit dan tidak dibuat langsung oleh guru sehingga belum sesuai dengan kebutuhan siswa.

LKPD yang ada di sekolah juga belum menampilkan karakter dan keterampilan yang harus dikuasai siswa yaitu salah satunya keterampilan menyelesaikan masalah. Kegiatan pembelajaran di SDN Kecamatan Tegineneng Kabupaten pesawaran tidak lepas dari penggunaan LKPD. Mengingat pentingnya LKPD dalam kegiatan belajar mengajar maka perlu diperhatikan kualitasnya baik dari segi isi, desain, media dan metode pengembangannya. Melalui LKPD berbasis Problem Based Learning berfikir kritis siswa dalam pembelajaran dapat ditingkatkan, penyampaian materi pelajaran dapat dipermudah dengan menggunakan LKPD.

Berbagai uraian dan masalah yang telah peneliti paparkan di atas, maka perlu mengembangkan LKPD berbasis Problem Based Learning (PBL) yang dapat meningkatkan keterampilan berpikir kritis. Terampil dalam memecahkan masalah dan menumbuhkan sikap kerjasama, mandiri, teliti dan punya keingintahuan yang besar terhadap sesuatu yang baru.

\section{METODE PENELITIAN}

Jenis penelitian ini adalah penelitian dan pengembangan (Research and Development / R\&D). Tahap utama langkah-langkah dalam penelitian dan pengembangan mengacu pada penelitian dan pengembangan yang dikembangkan oleh (Borg, W. R., \& Gall, 1983) yaitu (1) mengumpulkan informasi dan penelitian pendahuluan, (2) perencanaan; (3) produk pengembangan; (4) pengujian terbatas; dan (5) revisi produk akhir. Populasi dalam penelitian ini adalah para pendidik kelas V SD Negeri Kecamatan Tegineneng. Teknik pengambilan sampel yang digunakan adalah teknik purposive sampling. Sampel penelitian adalah 3 (tiga) guru kelas V SDN 28 Tegineneng, SDN 20 Tegineneng dan SDN 1 Tegineneng. Teknik pengumpulan data menggunakan observasi dan kuesioner. Teknik analisis data dalam penelitian ini menggunakan analisis deskriptif kualitatif teknik. Hasil analisis data digunakan sebagai dasar untuk merevisi produk yang dikembangkan. Itu pedoman penilaian dapat dilihat pada Tabel 1.

Tabel 1. Validasi Instrumen Analisis Skoring

\begin{tabular}{c|l|c}
\hline No & \multicolumn{1}{|c|}{ Pilihan Jawaban } & Skor \\
\hline 1 & Sangat Baik & 5 \\
2 & Baik & 4 \\
3 & Cukup & 3 \\
4 & Kurang & 2 \\
5 & Sangat Kurang & 1 \\
\hline
\end{tabular}

Nilai yang diberikan adalah satu sampai lima untuk jawaban sangat baik, baik, cukup, kurang, dan sangat kurang. Data interval tersebut dapat dianalisis dengan menghitung rata-rata jawaban berdasarkan skoring setiap jawaban dari ahli. 


$$
\text { Persentase Jawaban }=\frac{\text { Jumlah skor }- \text { Skor minimal }}{\text { Skor maksimal }- \text { skor minimal }} \quad x 100 \%
$$

Selanjutnya persentase kelayakan yang didapatkan kemudian diinterpretasikan ke dalam kategori kelayakan berdasarkan tabel. 2

Tabel 2. Kriteria Kelayakan

\begin{tabular}{c|c}
\hline Skor Persentase (\%) & Interprestasi \\
\hline $0 \%-20 \%$ & Sangat tidak layak \\
\hline $21 \%-40 \%$ & Kurang layak \\
\hline $41 \%-60 \%$ & Cukup \\
\hline $61 \%-80 \%$ & Layak \\
\hline $81 \%-100 \%$ & Sangat layak \\
\hline
\end{tabular}

\section{HASIL DAN PEMBAHASAN}

Sebelum proses pengembangan produk, peneliti terlebih dahulu melakukan studi pendahuluan atau analisis kebutuhan melalui penyebaran kuesioner mengenai kemampuan berpikir kritis. dengan subjek 90 siswa kelas V SD Negeri Tegineneng yang menerapkan kurikulum 2013. Kuesioner terdiri dari 20 pernyataan yaitu disusun berdasarkan aspek keterampilan berpikir lancar, berpikir luwes, berpikir orisinal, dan detail berpikir. Berdasarkan hasil angket berpikir kritis siswa diperoleh hasil bahwa $26,67 \%$ siswa senang melakukan kegiatan eksperimen (termasuk aspek detailing), sedangkan 73,33\% siswa siswa tidak suka melakukan kegiatan percobaan. Ini karena eksperimental atau eksperimental kegiatan dalam menemukan konsep matematika yang dilakukan kurang menarik atau terlalu kompleks.

Selanjutnya, 56,20\% siswa tidak suka memberikan contoh yang berbeda dengan yang sudah ada contoh (termasuk aspek asli dari pemikiran). Hal ini dikarenakan siswa sudah terbiasa dihadapkan dengan masalah matematika yang hanya pada tingkat pengetahuan dan pemahaman. Sebanyak 43,50\% siswa mudah melihat kesalahan dalam menyelesaikan masalah (termasuk aspek berfikir lancar). Hal ini dikarenakan siswa tidak diberi kesempatan untuk melakukan analisis masalah matematika. Berbasis Pada hasil angket, ketiga indikator di atas dari sepuluh indikator yang ada dalam angket kemampuan berpikir kritis siswa memiliki hasil perhitungan di bawah 50\%. Pemikiran kritis siswamempunyai kemampuan rendah pada aspek berpikir lancar, orisinal, dan mendetail.

Hasil analisis kebutuhan LKPD juga dilakukan di tiga sekolah yang berbeda, analisis di tujukan untuk guru kelas $\mathrm{V}$ yang dilakukan dengan mengisi kuesioner. Berdasarkan hasil angket terdapat $72 \%$ guru yang tidak membuat LKPD sendiri dan 100\% LKPD disusun tidak memuat struktur LKPD (judul, petunjuk studi, kompetensi yang ingin dicapai, informasi pendukung, dan penilaian).

LKPD yang digunakan disekolah belum mampu meningkatkan berfikir kritis siswa, LKPD yang digunakan juga tidak memfasilitasi perbedaan gaya belajar siswa. Berdasarkan uraian tersebut, kondisi dan potensi tersebut mendukung pengembang untuk mengembangkan bahan ajar berupa LKPD berbasis Problem Based Learning.

LKPD yang digunakan belum dapat mencapai proses pengembangan produk awal berdasarkan analisis kebutuhan dan penelaahan Inti Kompetensi dan Kompetensi Dasar. LKPD yang disusun kemudian akan divalidasi oleh dua orang validasi ahli materi dua orang validasi ahli desain dan dua orang validasi ahli media. Hasil validasi ahli dapat dilihat pada tabel 3. 
DOI : https://doi.org/10.31004/basicedu.v5i2.846

Tabel 3. Hasil validasi ahli materi

\begin{tabular}{clcccc}
\hline No & Aspek yang dinilai & Ahli 1 & Ahli 2 & Skor & Skor Maksimal \\
\hline 1 & Kesesuaian LKPD berbasis PBL & 60 & 59 & 120 & 130 \\
2 & Kesesuaian isi LKPD & 47 & 45 & 92 & 100 \\
& Skor & & & $\mathbf{2 1 2}$ & $\mathbf{2 3 0}$ \\
& Nilai & & & & $\mathbf{9 2 , 1 7}$ \\
\hline
\end{tabular}

Berdasarkan Tabel.3 dapat dilihat hasil validasi ahli materi berbasis Problem Based Learning Produk LKPD memperoleh persentase $92,17 \%$ dengan kriteria sangat layak. Selanjutnya hasil Validasi ahli desain dapat dilihat pada Tabel 4.

Tabel 4. Hasil validasi ahli desain

\begin{tabular}{clcccc}
\hline No & \multicolumn{1}{c}{ Aspek yang dinilai } & Ahli 1 & Ahli 2 & Skor & Skor Maksimal \\
\hline 1 & Kesesuaian LKPD dengan persyaratan didaktik & 39 & 42 & 81 & 90 \\
2 & Kualitas LKPD dengan persyaratan konstruksi & 20 & 23 & 43 & 50 \\
3 & Kesesuaian LKPD dengan syarat teknis & 40 & 44 & 84 & 100 \\
& Skor & & & $\mathbf{2 0 8}$ & $\mathbf{2 4 0}$ \\
& Nilai & & & & $\mathbf{8 6 , 6 7}$ \\
\hline
\end{tabular}

Berdasarkan Tabel. 4 terlihat bahwa nilai hasil validasi ahli desain pada Produk LKPD berbasis Problem Based Learning yang diperoleh dengan persentase 86,67\% dengan kategori sangat layak. Selanjutnya hasil Validasi ahli desain dapat dilihat pada Tabel. 5

Tabel 5. Hasil validasi ahli media

\begin{tabular}{clcccc}
\hline No & \multicolumn{1}{c}{ Aspek yang dinilai } & Ahli 1 & Ahli 2 & Skor & Skor Maksimal \\
\hline 1 & Kesesuaian media LKPD berbasis PBL & 56 & 59 & 115 & 130 \\
2 & Kesesuaian isi LKPD media pembelajaran & 44 & 47 & 91 & 100 \\
& Skor & & & $\mathbf{2 0 6}$ & $\mathbf{2 3 0}$ \\
& Nilai & & & & $\mathbf{8 9 , 5 6}$ \\
\hline
\end{tabular}

Berdasarkan Tabel. 5 terlihat bahwa nilai hasil validasi ahli media pada Produk LKPD berbasis Problem Based Learning yang diperoleh dengan persentase $89,56 \%$ dengan kategori sangat layak. Melalui Proses revisi, produk yang siap diujicobakan terbatas pada guru (praktisi). Hasil Hasil validasi oleh guru dapat dilihat pada Tabel. 6.

Tabel 6. Hasil validasi guru

\begin{tabular}{clccccc}
\hline & & Guru & Guru & Guru & & Skor \\
No & \multicolumn{1}{c}{ Aspek yang dinilai } & $\mathbf{1}$ & $\mathbf{2}$ & $\mathbf{3}$ & Skor & Maksimal \\
\hline 1 & Kesesuaian LKPD berbasis PBL & 61 & 65 & 59 & 185 & 195 \\
2 & Kesesuaian isi LKPD & 47 & 46 & 48 & 141 & 150 \\
3 & Kesesuaian LKPD dengan persyaratan didaktik & 41 & 38 & 42 & 121 & 135 \\
4 & Kualitas LKPD dengan persyaratan konstruksi & 23 & 24 & 20 & 67 & 75 \\
5 & Kesesuaian LKPD dengan syarat teknis & 48 & 50 & 47 & 145 & 150 \\
6 & Kesesuaian media LKPD berbasis PBL & 40 & 37 & 41 & 118 & 135 \\
7 & Kesesuaian isi LKPD media pembelajaran & 22 & 23 & 21 & 66 & 75 \\
& Skor & & & & $\mathbf{8 4 3}$ & $\mathbf{9 1 5}$ \\
& Niali & & & & & $\mathbf{9 2 , 1 3}$ \\
\hline
\end{tabular}


Berdasarkan Tabel 6 terlihat bahwa hasil penilaian produk LKPD berbasis Problem Based Learning oleh guru berjumlah 92,13 dengan kriteria sangat layak.

LKPD berbasis Problem Based Learning yang dikembangkan dapat dilihat pada tabel 1-6. Setelah merevisi saran dan masukan dari ahli materi, ahli desain, ahli media dan guru, diperoleh produk akhir berupa LKPD berbasis Problem Based Learning untuk kemampuan berpikir kritis untuk siswa kelas V SD. yang sangat cocok digunakan dalam pembelajaran

Pengembangan LKPD berbasis Problem Based Learning, produk yang dikembangkan telah memenuhi konsep pembelajaran dan pembelajaran. Berdasarkan landasan teori pembelajaran konstruktivisme, pembelajaran merupakan hasil konstruksi siswa sebagai hasil interaksinya dengan lingkungan. Menurut (Susanto, 2016) belajar menurut teori konstruktivisme adalah bahwa siswa harus mencari tahu sendiri dan mengubah informasi yang kompleks, memeriksa informasi baru dengan aturan lama, dan merevisinya jika aturan tersebut tidak berlaku lagi.

Menurut Vigotsky (Trianto, 2010), proses belajar akan terjadi jika anak bekerja atau menangani tugastugas yang belum dipelajari, tetapi tugas-tugas itu masih dalam jangkauannya yang biasanya disebut zona perkembangan proksimal, yang merupakan tingkat perkembangan sedikit di atas kemampuannya. Ide penting lainnya dari Vigotsky adalah Scaffolding, yaitu memberikan bantuan kepada anak-anak pada tahap awal perkembangan dan mengurangi bantuan serta memberikan kesempatan kepada anak untuk mengambil alih tanggung jawab yang lebih besar setelah anak dapat melakukannya. Interpretasi terbaru dari ide-ide Vigotsky adalah bahwa siswa harus diberi tugas yang kompleks, sulit dan realistis yang kemudian diberikan bantuan yang cukup untuk menyelesaikan tugas (Tohir, 2015).

Oleh karena itu, pengembangan LKPD berbasis Problem Based Learning dirancang agar siswa dapat mengamati, mengalaminya sendiri, dan memperoleh informasi yang tersedia di LKPD berupa teks, gambar, ilustrasi, atau langkah-langkah kegiatan, sehingga mendorong siswa untuk mengkonstruksi pengetahuan dengan pengalamannya sendiri.

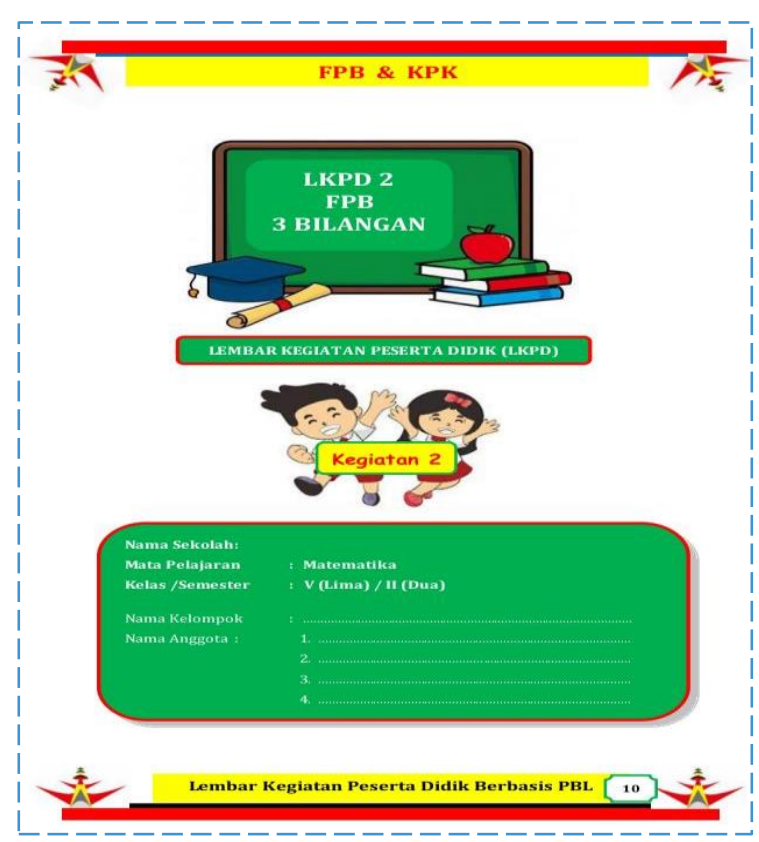

Gambar 1. Tampilan LKPD

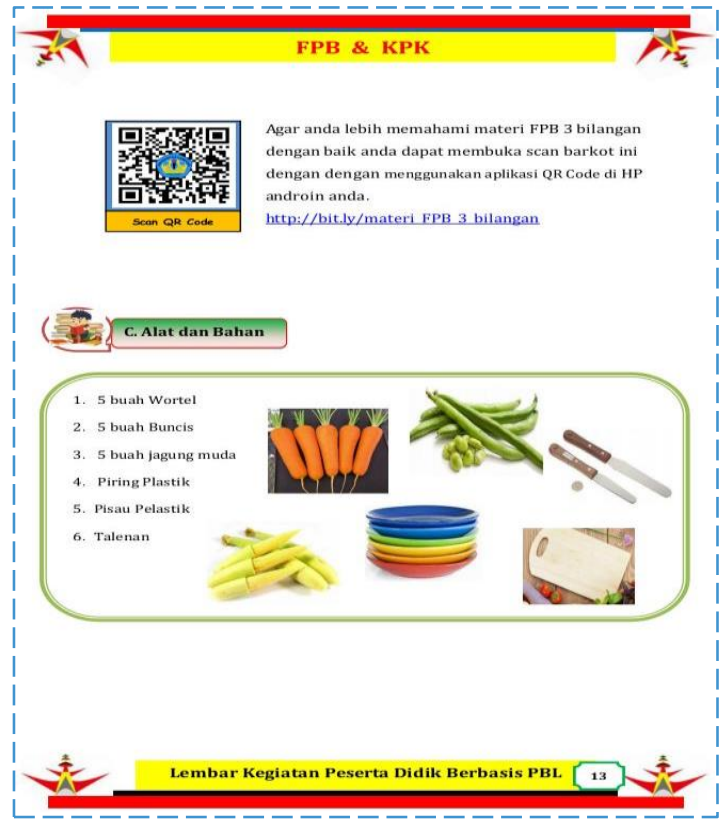

Gambar 2. Tampilan alat dan bahan 


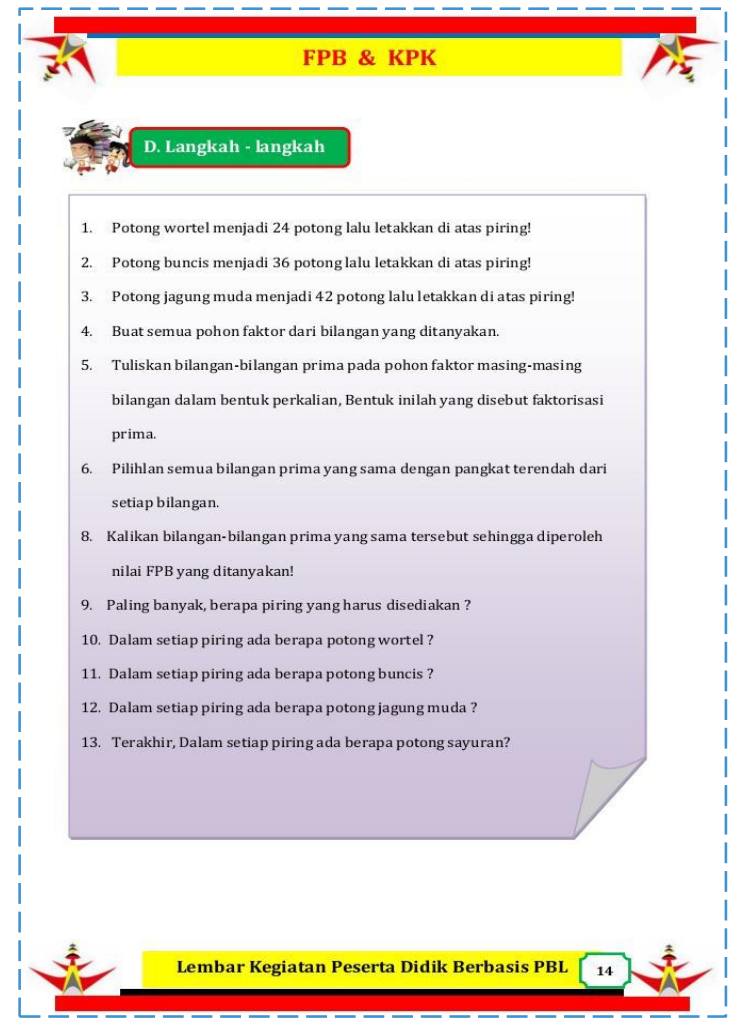

Gambar 3. Tampilan langkah-langkah

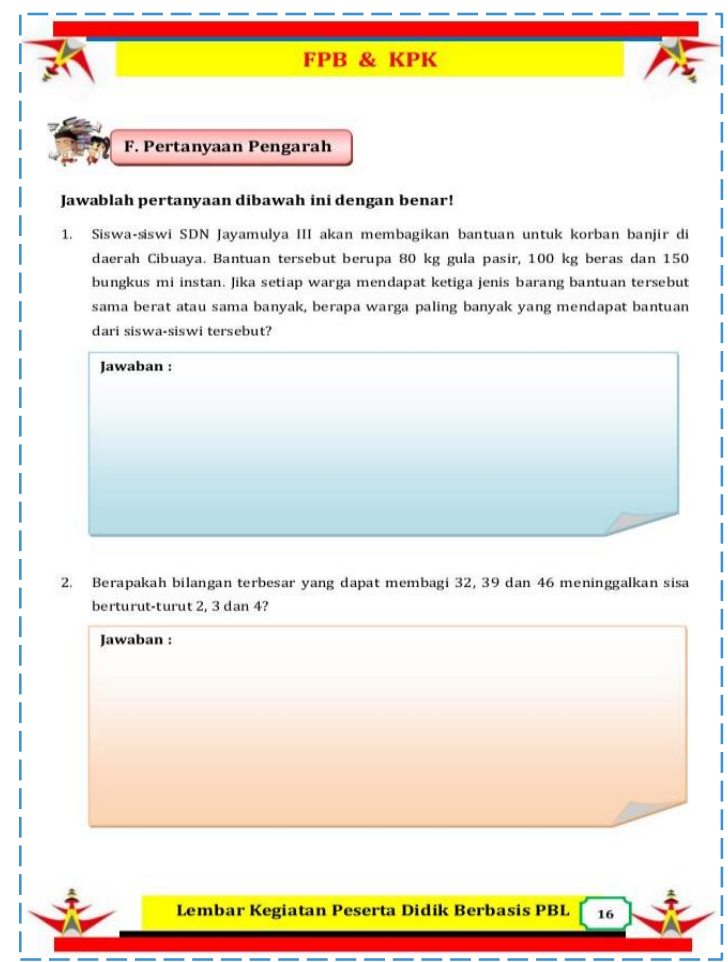

Gambar 5. Tampilan pertanyaan pengarah

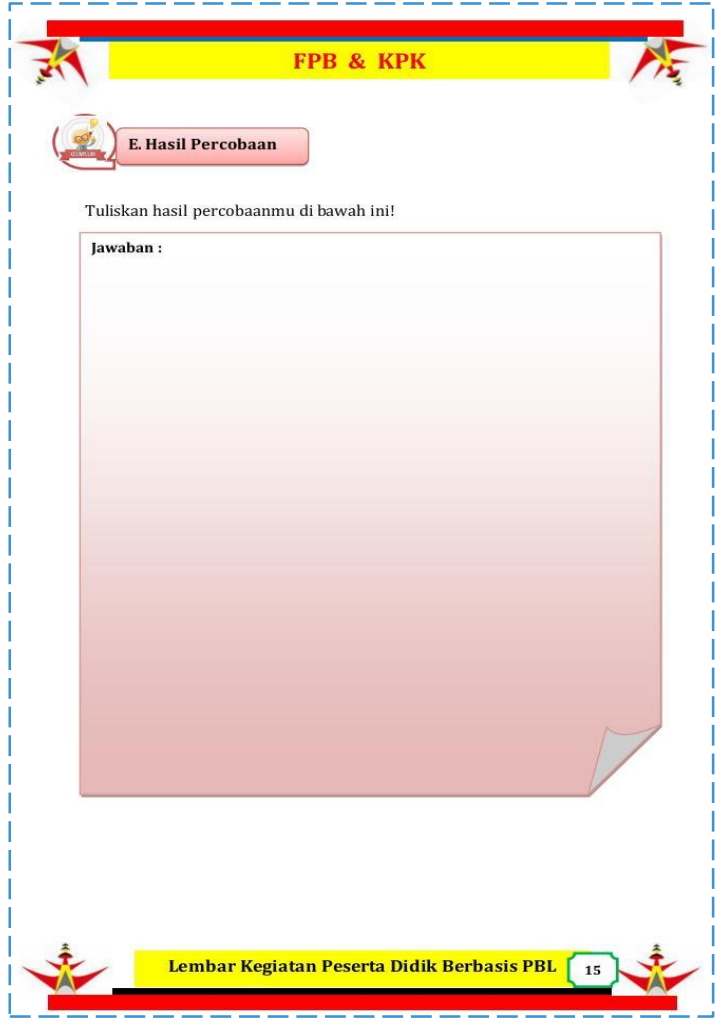

Gambar 4. Tampilan hasil percobaan

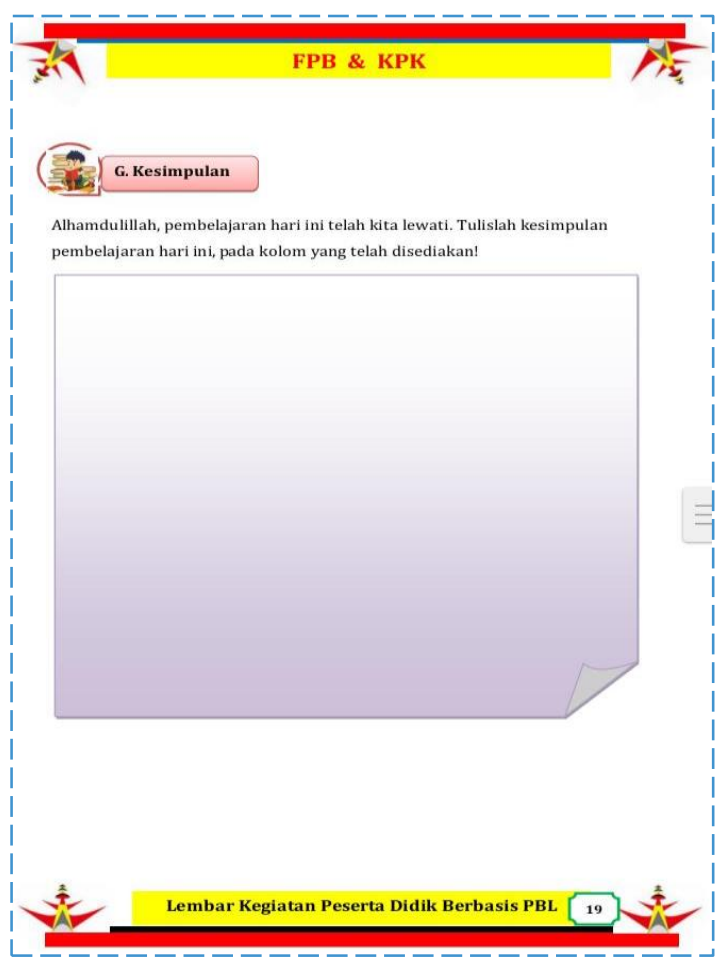

Gambar 6. Tampilan kesimpulan 
LKPD berbasis Problem Based Learning dinilai sangat layak berdasarkan ahli materi, ahli desain, ahli media dan praktisi. Hasil penelitian ini didukung oleh penelitian yang dilakukan oleh (Utami dkk., 2018) Hasil penelitian menunjukkan bahwa LKPD matematika dengan pendekatan Problem Based Learning dinilai sesuai dengan penilaian sangat layak. Selain itu, penelitian yang dilakukan oleh (Noer \& Gunowibowo, 2018) menampilkan materi LKPD untuk dua pelajaran. Hasil dari kedua uji coba tersebut dijadikan acuan untuk melakukan revisi produk tahap sehingga menghasilkan produk akhir Lembar Kegiatan Peserta Didik materi FPB dan KPK berbasis Problem Based Learning.

Hasil pengembangan produk LKPD adalah sebagai berikut : Pertama, matematika berisi materi pelajaran dengan kompetensi dasar sebagai berikut : (3.5) memecahkan masalah yang berkaitan dengan FPB dan KPK; (4.5) Menyelesaikan masalah yang berkaitan dengan dengan FPB dan KPK. Kedua, LKPD dikembangkan berdasarkan Problem Based Learning. Ketiga, LKPD yang dikembangkan berisi indikator keterampilan berpikir kritis siswa.

Selain itu, LKPD yang dikembangkan dapat mendukung proses pembelajaran, membantu siswa menjadi lebih mudah memahami materi dan dapat melatih siswa untuk berpikir kritis. Ini sesuai dengan penelitian Jurnal (Sulistyorini, S., 2018) yaitu pengembangan LKPD dilakukan untuk mendukung siswa dalam proses pembelajaran, membantu siswa memahami materi, dan melatih siswa agar berpikir kritis mereka dapat memecahkan masalah yang terjadi di sekitar mereka. Selain itu menurut Depdiknas (Sulistyorini, S., 2018), Lembar Kerja Peserta Didik (LKPD) merupakan lembar yang berisi tugas-tugas yang harus dikerjakan siswa. Lembar kegiatan biasanya berupa instruksi-instruksi, langkah-langkah untuk menyelesaikan tugas. Keuntungan menggunakan LKPD adalah memudahkan pendidik dalam melaksanakan pembelajaran, bagi siswa akan lebih mudah lebih mudah belajar mandiri dan belajar memahami serta melaksanakan tugas tertulis.

Apa yang telah dijelaskan di atas telah menunjukkan bahwa pentingnya mengembangkan LKPD berbasis Problem Based Learning. LKPD ini sebagai motivasi belajar dan meningkatkan kemampuan berpikir kritis siswa. Dengan bantuan LKPD Siswa akan berusaha keras untuk memecahkan suatu masalah yang diberikan oleh gurunya. Sangat penting untuk merumuskan kalimat tentang masalah yang akan dipresentasikan siswa dengan cara yang menarik, terkait dengan kehidupan sehari-hari agar tidak terlalu abstrak, dan dapat diselesaikan oleh siswa, baik dengan bantuan atau tanpa bantuan guru. Proses pembelajaran yang mengkondisikan siswa belajar kelompok dan bertukar pikiran akan membuat siswa terbiasa memimpin investigasi, biasanya dimulai dengan skrining masalah nyata yang pernah dialami. Berdasarkan penjelasan diatas dapat disimpulkan bahwa LKPD Matematika berbasis Problem Based Learning telah dapat dikatakan layak untuk di gunakan.

\section{KESIMPULAN}

Pengembangan LKPD Matematika berbasis Problem Based Learning pada materi FPB dan KPK di kelas V SDN 28 Tegineneng telah memberikan satu alternatif bagi guru dalam meningkatkan proses belajar dan mengajar di kelas. Penelitian pengembangan ini telah menghasilkan LKPD Matematika. LKPD Matematika pada materi FPB dan KPK telah melalui uji validitas oleh pakar dan dosen yang ahli di bidangnya. Dengan uji validitas ini maka LKPD ini talah dikategorikan valid.

Berdasarkan hasil penelitian dan pembahasan dapat disimpulkan bahwa pengembangan LKPD Matematika berbasis Problem Based Learning di Sekolah Dasar Kecamatan Tegineneng sangat layak untuk dilakukan digunakan dalam pembelajaran. Hal tersebut berdasarkan hasil validasi ahli materi sebesar 92,17\%, hasil validasi ahli desain sebesar $86,67 \%$, hasil validasi ahli media sebesar $89,56 \%$ dan hasil tes kepada guru sebesar 92,13\%. 
LKPD Matematika berbasis Problem Based Learning ini dapat menjadi motivasi bagi guru untuk mempergunakannya dalam proses pembelajaran di kelas. Kepala sekolah dapat merekomendasikan kepada guru di sekolah dengan harapan dapat menjadi motivasi dalam merancang LKPD Matematika yang sesuai kebutuhan siswa. Bagi guru, berdasarkan hasil validasi maka LKPD Matematika berbasis Problem Based Learning ini dapat menjadi salah satu pilihan bagi guru dalam menciptakan kegiatan belajar yang lebih bermakna.

\section{DAFTAR PUSTAKA}

Bialik, M., \& Fadel, C. (2015). Skills for the 21 st Century: What should students learn? Skills for the 21st Century: What Should Students Learn?, 5.

Borg, W. R., \& Gall, G. (1983). Educational research: An introduction, Fifth Edition. Longman.

Choo, S. S. Y., Rotgans, J. I., Yew, E. H. J., \& Schmidt, H. G. (2011). Effect of worksheet scaffolds on student learning in problem-based learning. Advances in Health Sciences Education, 16(4), 517-528. https://doi.org/10.1007/s10459-011-9288-1

Damayanti, R., \& Mawardi, M. (2018). Developing of MITRA learning model of problem solving-based to solve mathematical problems in elementary school. Jurnal Prima Edukasia, 6(1), 1-10. https://doi.org/10.21831/jpe.v6i1.17238

Depdiknas. (2006). Lampiran 1 Permendiknas Nomor 22 Tahun 2006 tentang Standar Isi. Depdiknas.

Noer, S. H., \& Gunowibowo, P. (2018). Efektivitas Problem Based Learning Ditinjau Dari Kemampuan Berpikir Kritis Dan Representasi Matematis. Jurnal Penelitian Dan Pembelajaran Matematika, 11(2). https://doi.org/10.30870/jppm.v11i2.3751

Prastowo, A. (2011). Panduan kreatif membuat bahan ajar inovatif. Diva Press.

Ronis, D. (2001). Problem Based Learning for Mathand Science. Skylight Training and Publising Inc.

Sriwongchai, A. (2015). Developing the Mathematics Learning Management Model for Improving Creative Thinking In Thailand. International Education Studies, 8(11), 77. https://doi.org/10.5539/ies.v8n11p77

Sulistyorini, S., \& A. Z. (2018). Pengembangan Lembar Kerja Peserta Didik (Lkpd) Tematik Terpadu Mengintegrasikan Penguatan Pendidikan Karakter (Ppk) Dan Literasi Siswa Sd Di Kota Semarang. Pengembangan Lembar Kerja Peserta Didik (Lkpd) Tematik Terpadu Mengintegrasikan Penguatan Pendidikan Karakter (Ppk) Dan Literasi Siswa Sd Di Kota Semarang, 9(1), 21-30.

Susanto, A. (2016). Teori belajar \& pembelajaran di sekolah dasar. Kencana.

Tohir, A. (2015). Pengembangan bahan ajar modul kesetimbangan kimia berbasis multipel representasi di SMA Kota Bandar Lampung. Program Pascasarjana Teknologi Pendidikan Fakultas Keguruan Dan Ilmu Pendidikan Universitas Lampung.

Trianto. (2010). Model pembelajaran terpadu. Bumi Aksara.

Utami, P. R., Junaedi, I., \& Hidayah, I. (2018). "Mathematical Representation Ability of Students' Grade X in Mathematics Learning on Problem Based Learning". Unnes Journal of Mathematics Education, 7(3), 164-171. https://doi.org/10.15294/ujme.v7i1.25486

Yasir, M. (2013). Pengembangan Lembar Kerja Siswa (Lks) Berbasis Strategi Belajar Metakognitif Untuk Meningkatkan Hasil Belajar Siswa Pada Materi Pewarisan Sifat Manusia. BioEdu, 2(1), 77-83. 